Article

\title{
Discrete and Polymeric, Mono- and Dinuclear Silver Complexes of a Macrocyclic Tetraoxime Ligand with $\mathbf{A g}^{\mathrm{I}}-\mathbf{A g}^{\mathrm{I}}$ Interactions
}

\author{
Shohei Tashiro, Jun-ichiro Tanihira, Mihoko Yamada and Mitsuhiko Shionoya * \\ Department of Chemistry, Graduate School of Science, the University of Tokyo, 7-3-1 Hongo, \\ Bunkyo-ku, Tokyo 113-0033, Japan; E-Mails: tashiro@chem.s.u-tokyo.ac.jp (S.T.); \\ tanihira@chem.s.u-tokyo.ac.jp (J.T.); myamada@chem.eng.osaka-u.ac.jp (M.Y.) \\ * Author to whom correspondence should be addressed; E-Mail: shionoya @ chem.s.u-tokyo.ac.jp; \\ Tel./Fax: +81-3-5841-8061.
}

Received: 3 March 2013; in revised form: 22 April 2013 / Accepted: 27 April 2013 /

Published: 2 May 2013

\begin{abstract}
Macrocyclic compounds that can bind cationic species efficiently and selectively with their cyclic cavities have great potential as excellent chemosensors for metal ions. Recently, we have developed a tetraoxime-type tetraazamacrocyclic ligand $\mathbf{1}$ formed through a facile one-pot cyclization reaction. Aiming to explore and bring out the potential of the tetraoxime macrocycle $\mathbf{1}$ as a chelating sensor, we report herein the preparation of several kinds of silver complexes of $\mathbf{1}$ and their unique coordination structures determined by single-crystal X-ray diffraction analyses. As a result, the formation of two kinds of discrete structures, monomeric complexes $[\operatorname{Ag}(\mathbf{1}) \mathrm{X}](\mathrm{X}=$ counter anions) and a dimeric complex $\left[\operatorname{Ag}_{2}(\mathbf{1})_{2}\right] X_{2}$, and two kinds of polymeric structures from a mononuclear complex, $[\operatorname{Ag}(\mathbf{1})]_{n} \mathrm{X}_{n}$, and from a dinuclear complex, $\left[\operatorname{Ag}_{2}(\mathbf{1}) \mathrm{X}_{2}\right]_{n}$, was demonstrated. In the resulting complexes, the structurally flexible macrocyclic ligand $\mathbf{1}$ was found to provide several different coordination modes. Notably, in some silver complexes of $1, \mathrm{Ag}^{\mathrm{I}}-\mathrm{Ag}^{\mathrm{I}}$ interactions were observed with different $A g^{\mathrm{I}}-\mathrm{Ag}^{\mathrm{I}}$ distances which depend on the kind of counter anions and the chemical composition.
\end{abstract}

Keywords: silver; macrocycle; oxime; crystal; metal-metal interaction 


\section{Introduction}

In the molecular design of chemosensors, macrocyclic compounds provide excellent structural and functional motifs due to their efficient and specific binding to analytes through multipoint interactions within restricted cyclic skeletons. So far, a great number of macrocyclic compounds such as crown ethers [1], cryptands [2], cyclic polyamines [3], porphyrins [4] and Schiff-base macrocycles [5] have been extensively used for cation [6] and anion [7] sensing by covalently attached chromophores, luminophores [8-10] or redox-active moieties [11], and for indicator-displacement assays (IDAs) in which an indicator molecule non-covalently bound to a host molecule is displaced by an analyte to cause signaling [12]. Recently, arrangement or immobilization of macrocycles on several interfaces or nanometer-sized materials allows for more practical sensing applications [13-15]. Therefore, while selection and combination of the signaling moieties are obviously important, it will also be necessary to develop novel chemically modifiable macrocyclic skeletons capable of binding analytes in well-defined modes.

Previously we reported the synthesis of a tetraoxime-type tetraazamacrocycle, 3,7,11,15-tetramethyl-1,5,9,13,2,6,10,14-tetraoxatetraazacyclohexa-2,6,10,14-tetraene (1), by facile metal-template one-pot cyclization of a simple dioxime-type compound [16]. The macrocyclic ligand $\mathbf{1}$ can complex with various divalent transition metal ions such as $\mathrm{Fe}^{\mathrm{II}}, \mathrm{Ni}^{\mathrm{II}}, \mathrm{Cu}^{\mathrm{II}}$ and $\mathrm{Pd}^{\mathrm{II}}$ to form six-coordinate octahedral and four-coordinate square-planar structures. Notably, macrocycle $\mathbf{1}$ has a flexible, larger 16-membered cyclic skeleton compared with widely-used tetraazamacrocycles such as a 12-membered cyclen and a 14-membered cyclam. Moreover, the oxime nitrogen donors of $\mathbf{1}$ generally show lower Lewis basicity than nitrogen donors such as amine, imine and hydrazone. A unique coordination structure based on these features was preliminarily found in a crystalline, linear polymeric $\mathrm{Ag}^{\mathrm{I}}$ complex in which $\mathrm{Ag}_{2} \mathrm{~L}_{1}$-type dinuclear complexes are bridged by counter anions [16].

Figure 1. Schematic representation of the formation of four types of $\mathrm{Ag}^{\mathrm{I}}$ complexes of $\mathbf{1}$ with discrete or polymeric structures.

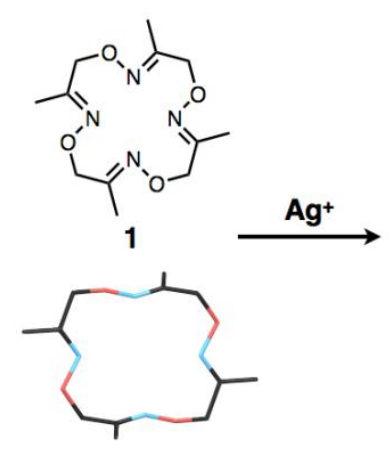

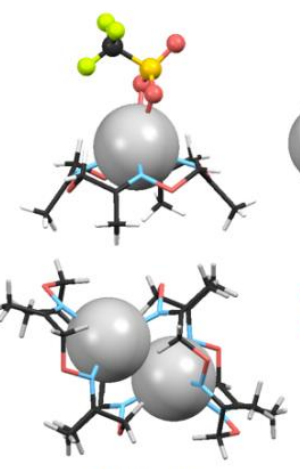

$\underline{\text { Discrete }}$
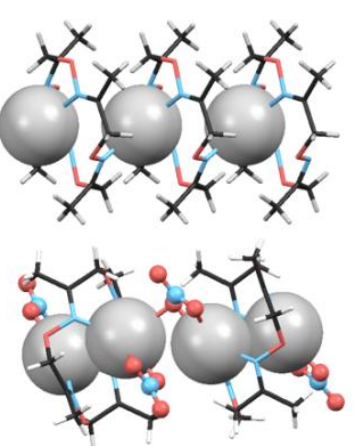

$\underline{\text { Polymeric }}$

As part of the development of the metal binding ability of $\mathbf{1}$ as a basic structure of chemosensors, we found that ligand $\mathbf{1}$, depending on the kind of $\mathrm{Ag}^{\mathrm{I}}$ salts, forms a variety of discrete or polymeric $\mathrm{Ag}^{\mathrm{I}}$ complexes with different compositional ratios such as $[\mathrm{Ag}(\mathbf{1})],\left[\operatorname{Ag}_{2}(\mathbf{1})_{2}\right]$ and $\left[\operatorname{Ag}_{2}(\mathbf{1})\right]$ in the crystalline state (Figure 1). We also found $\mathrm{Ag}^{\mathrm{I}}-\mathrm{Ag}^{\mathrm{I}}$ interactions in some crystal structures, in which the distances between two $\mathrm{Ag}^{\mathrm{I}}$ ions vary with the kind of counter anions and/or the ligand-to-metal ratios. It is well 
known that metal-metal interactions of $\mathrm{d}^{10}$ metals such as $\mathrm{Cu}^{\mathrm{I}}, \mathrm{Ag}^{\mathrm{I}}$ and $\mathrm{Au}^{\mathrm{I}}$ ions and square planar $\mathrm{d}^{8}$ metals such as $\mathrm{Rh}^{\mathrm{I}}, \mathrm{Pd}^{\mathrm{II}}$ and $\mathrm{Pt}^{\mathrm{II}}$ ions produce characteristic luminescence with appropriate ligands [17-21]. Although we have not so far observed such behaviour of the $\mathrm{Ag}^{\mathrm{I}}$ complexes of $\mathbf{1}$, ligands capable of mediating metal-metal interactions would have great potential to serve as a luminescent chemosensor with appropriate bridging ligands or additional pendant ligand on the macrocycle.

\section{Experimental Section}

\subsection{General Procedures}

All solvents, organic and inorganic reagents except for the macrocyclic ligand $\mathbf{1}$ are commercially available, and were used without further purification. The ligand $\mathbf{1}$ was synthesised and isolated as colorless crystals via formation of the ferrous complex, $\left[\mathrm{Fe}(\mathbf{1})\left(\mathrm{CH}_{3} \mathrm{CN}\right)_{2}\right]\left(\mathrm{ClO}_{4}\right)_{2}$, according to our previous report [16]. Crystallisation of silver complexes was carried out in the dark. Single-crystal X-ray crystallographic analyses were performed using a Rigaku RAXIS-RAPID imaging plate diffractometer with $\operatorname{MoK} \alpha(\lambda=0.71075 \AA)$ radiation, and data obtained were calculated using the CrystalStructure crystallographic software package except for refinement, which was performed using SHELXL-97 [22]. Crystallographic data and refinement details for obtained five complexes are shown in Table 1. The X-ray structures are displayed using the Mercury program.

Table 1. Crystallographic data and refinement details for $\left[\operatorname{Ag}(\mathbf{1}) \mathrm{NO}_{3}\right],\left[\mathrm{Ag}(\mathbf{1}) \mathrm{CF}_{3} \mathrm{SO}_{3}\right]$, $\left[\mathrm{Ag}_{2}(\mathbf{1})_{2}\right]\left(\mathrm{SbF}_{6}\right)_{2},[\mathrm{Ag}(\mathbf{1})]_{n}\left(\mathrm{BF}_{4}\right)_{n}$ and $\left[\mathrm{Ag}_{2}(\mathbf{1})\left(\mathrm{NO}_{3}\right)_{2}\right]_{n}$.

\begin{tabular}{|c|c|c|c|c|c|}
\hline & {$\left[\mathrm{Ag}(\mathbf{1}) \mathrm{NO}_{3}\right]$} & {$\left[\mathrm{Ag}(\mathbf{1}) \mathrm{CF}_{3} \mathrm{SO}_{3}\right]$} & {$\left[\mathrm{Ag}_{2}(1)_{2}\right]\left(\mathrm{SbF}_{6}\right)_{2}$} & {$[\operatorname{Ag}(\mathbf{1})]_{n}\left(\mathbf{B F}_{4}\right)_{n}$} & {$\left[\mathrm{Ag}_{2}(\mathbf{1})\left(\mathrm{NO}_{3}\right)_{2}\right]_{n}$} \\
\hline Formula & $\mathrm{C}_{12} \mathrm{H}_{20} \mathrm{AgN}_{5} \mathrm{O}_{7}$ & $\mathrm{C}_{13} \mathrm{H}_{20} \mathrm{AgF}_{3} \mathrm{~N}_{4} \mathrm{O}_{7} \mathrm{~S}$ & $\mathrm{C}_{12} \mathrm{H}_{20} \mathrm{AgF}_{6} \mathrm{~N}_{4} \mathrm{O}_{4} \mathrm{Sb}$ & $\mathrm{C}_{12} \mathrm{H}_{20} \mathrm{AgBF}_{4} \mathrm{~N}_{4} \mathrm{O}_{4}$ & $\mathrm{C}_{12} \mathrm{H}_{20} \mathrm{Ag}_{2} \mathrm{~N}_{6} \mathrm{O}_{10}$ \\
\hline Formula weight & 454.19 & 541.25 & 627.92 & 478.99 & 624.06 \\
\hline Crystal system & triclinic & triclinic & orthorhombic & tetragonal & triclinic \\
\hline Space group & $P-1$ & $P-1$ & Pbca & $P 4 / n$ & $P-1$ \\
\hline$a(\AA)$ & $8.4448(14)$ & $8.442(2)$ & $16.0247(4)$ & $19.4458(15)$ & $8.0660(11)$ \\
\hline$b(\AA)$ & $10.5207(16)$ & $9.988(3)$ & $13.4358(3)$ & $19.4458(15)$ & $9.6775(13)$ \\
\hline$c(\AA)$ & $11.576(2)$ & $12.974(3)$ & $17.7726(5)$ & $4.3965(4)$ & $13.3698(15)$ \\
\hline$\alpha\left(^{\circ}\right)$ & $67.188(5)$ & $71.262(8)$ & 90 & 90 & $67.686(4)$ \\
\hline$\beta\left(^{\circ}\right)$ & $81.490(4)$ & $88.062(7)$ & 90 & 90 & $85.264(4)$ \\
\hline$\gamma\left({ }^{\circ}\right)$ & $63.784(3)$ & $69.975(7)$ & 90 & 90 & $84.658(5)$ \\
\hline$V\left(\AA^{3}\right)$ & $850.2(3)$ & $969.8(4)$ & $3826.51(17)$ & $1662.5(3)$ & $960.0(2)$ \\
\hline$Z$ & 2 & 2 & 8 & 4 & 2 \\
\hline$T(\mathrm{~K})$ & 93 & 93 & 93 & 108 & 93 \\
\hline$D_{\text {calcd }}\left(\mathrm{g} / \mathrm{cm}^{3}\right)$ & 1.774 & 1.853 & 2.180 & 1.914 & 2.159 \\
\hline$\mu\left(\mathrm{mm}^{-1}\right)$ & 1.228 & 1.217 & 2.514 & 1.279 & 2.101 \\
\hline $2 \theta_{\max }\left({ }^{\circ}\right)$ & 55 & 55 & 55 & 55 & 55 \\
\hline Reflns, total & 8344 & 9464 & 34764 & 22040 & 9440 \\
\hline Reflns, unique & 3841 & 4400 & 4384 & 1904 & 4341 \\
\hline$R_{\text {int }}$ & 0.0267 & 0.0372 & 0.0313 & 0.0600 & 0.0505 \\
\hline$R_{1}(I>2 \sigma(I))^{a}$ & 0.0241 & 0.0332 & 0.0179 & 0.1003 & 0.0560 \\
\hline$w R_{2}$ (all data) ${ }^{b}$ & 0.0626 & 0.1017 & 0.0403 & 0.2600 & 0.1743 \\
\hline GOF on $F^{2}$ & 1.083 & 1.131 & 1.180 & 1.118 & 1.118 \\
\hline CCDC numbers & 918055 & 918056 & 918057 & 918058 & 918059 \\
\hline
\end{tabular}

$\left.{ }^{a} R_{1}=\sum|| F_{o}|-| F_{c}\left|/ \sum\right| F_{o} \mid ;{ }^{b} w R_{2}=\left[\sum\left[w\left(F_{o}{ }^{2}-F_{c}{ }^{2}\right)^{2}\right] / \sum w\left(F_{o}{ }^{2}\right)^{2}\right]\right]^{1 / 2}$. 


\subsection{Crystallisation of $\left[\mathrm{Ag}(1) \mathrm{NO}_{3}\right]$}

Ligand $1(1.0 \mathrm{mg}, 3.5 \mu \mathrm{mol})$ and $\mathrm{AgNO}_{3}(5.9 \mathrm{mg}, 35 \mu \mathrm{mol})$ were dissolved in $\mathrm{CH}_{3} \mathrm{CN}(2 \mathrm{~mL})$. The resulting solution was slowly evaporated for 2 days at room temperature. Colorless block crystals appeared with a powder of excess silver salts. One of the crystals was analysed by single-crystal X-ray diffraction measurement.

\subsection{Crystallisation of $\left[\mathrm{Ag}(\mathrm{1}) \mathrm{CF}_{3} \mathrm{SO}_{3}\right]$}

Ligand 1 (1.0 mg, $3.5 \mu \mathrm{mol})$ and $\mathrm{AgCF}_{3} \mathrm{SO}_{3}(9.0 \mathrm{mg}, 35 \mu \mathrm{mol})$ were dissolved in $\mathrm{CH}_{3} \mathrm{CN}(1 \mathrm{~mL})$. After addition of toluene $(1 \mathrm{~mL})$, the resulting mixed solution was slowly evaporated for 1 week at room temperature. Colorless plate crystals appeared with powder of excess silver salts. One of the crystals was analysed by single-crystal X-ray diffraction measurement.

\subsection{Crystallisation of $\left[\mathrm{Ag}_{2}(1)_{2}\right]\left(\mathrm{SbF}_{6}\right)_{2}$}

Ligand $1(0.10 \mathrm{mg}, 0.35 \mu \mathrm{mol})$ and $\mathrm{AgSbF}_{6}(0.60 \mathrm{mg}, 1.75 \mu \mathrm{mol})$ were dissolved in $\mathrm{CHCl}_{3}$ $(0.25 \mathrm{~mL})$. The mixed solution was crystallised by slow diffusion of diethyl ether as a poor solvent at room temperature. After several days, colorless block crystals appeared and one of the crystals was analysed by single-crystal X-ray diffraction measurement.

\subsection{Crystallisation of $[\mathrm{Ag}(\mathbf{1})]_{n}\left(B F_{4}\right)_{n}$}

Ligand $1(0.23 \mathrm{mg}, 0.81 \mu \mathrm{mol})$ and $\mathrm{AgBF}_{4}(1.6 \mathrm{mg}, 8.2 \mu \mathrm{mol})$ were dissolved in $\mathrm{CH}_{3} \mathrm{CN}(0.25 \mathrm{~mL})$. After addition of toluene $(0.25 \mathrm{~mL})$, the resulting mixed solution was slowly evaporated for several days at room temperature. Colorless block crystals appeared with a powder of excess silver salts. One of the crystals was analysed by single-crystal X-ray diffraction measurement.

\subsection{Crystallisation of $\left[\mathrm{Ag}_{2}(\mathrm{1})\left(\mathrm{NO}_{3}\right)_{2}\right]_{n}$}

Ligand $1(1.0 \mathrm{mg}, 3.5 \mu \mathrm{mol})$ and $\mathrm{AgNO}_{3}(5.9 \mathrm{mg}, 35 \mu \mathrm{mol})$ were dissolved in $\mathrm{CH}_{3} \mathrm{CN}(1 \mathrm{~mL})$. After addition of toluene $(1 \mathrm{~mL})$, the resulting mixed solution was slowly evaporated for 1 week at room temperature. Colorless plate crystals appeared with a powder of excess silver salts. One of the crystals was analysed by single-crystal X-ray diffraction measurement.

\section{Results}

\subsection{Two Discrete, Mononuclear Silver Complexes, [ $\left.\mathrm{Ag}(\mathrm{1}) \mathrm{NO}_{3}\right]$ and $\left[\mathrm{Ag}(\mathrm{1}) \mathrm{CF}_{3} \mathrm{SO}_{3}\right]$}

To precisely evaluate the molecular structures of silver complexes of $\mathbf{1}$ by single-crystal X-ray diffraction analysis, we examined crystallisation of mixed solutions of $\mathbf{1}$ with several kinds of silver salts. Crystallisation of the mixed solution of 1 with 10 equivalents of $\mathrm{AgNO}_{3}$ or $\mathrm{AgCF}_{3} \mathrm{SO}_{3}$ salts afforded similar mononuclear complexes, $\left[\mathrm{Ag}(\mathbf{1}) \mathrm{NO}_{3}\right]$ or $\left[\mathrm{Ag}(\mathbf{1}) \mathrm{CF}_{3} \mathrm{SO}_{3}\right]$, respectively. For example, when ligand 1 and $\mathrm{AgNO}_{3}$ were dissolved in $\mathrm{CH}_{3} \mathrm{CN}$, colorless block crystals were obtained after slow evaporation. Single-crystal X-ray analysis of the resulting block crystal revealed the molecular 
structure of a neutral, mononuclear silver complex, $\left[\operatorname{Ag}(\mathbf{1}) \mathrm{NO}_{3}\right]$ (Figure 2(a)). In this structure, four nitrogen atoms of $\mathbf{1}$ and two oxygen atoms of an $\mathrm{NO}_{3}{ }^{-}$ion bind to an $\mathrm{Ag}^{\mathrm{I}}$ ion to form a six-coordinate structure (Figure 2(b)). The bound $\mathrm{Ag}^{\mathrm{I}}$ ion does not fit into the $\mathrm{N}_{4}$-plane of $\mathbf{1}$, but sits on the four upturned nitrogen atoms of $\mathbf{1}$, resulting in the formation of a shuttlecock-like structure (Figure 2(c)). The structure of $\left[\operatorname{Ag}(\mathbf{1}) \mathrm{NO}_{3}\right]$ is chiral so that both enantiomers exist in the crystal as a racemate.

Figure 2. Crystal structures of $(\mathbf{a}-\mathbf{c})\left[\mathrm{Ag}(\mathbf{1}) \mathrm{NO}_{3}\right]$ and $(\mathbf{d}-\mathbf{f})\left[\mathrm{Ag}(\mathbf{1}) \mathrm{CF}_{3} \mathrm{SO}_{3}\right]$. (a,d) Top views and (b,e) coordination structures represented with 50\% thermal ellipsoids; (c,f) Side views represented with space fill (Ag), stick (1) and ball-stick (counter anions) models.

(a)

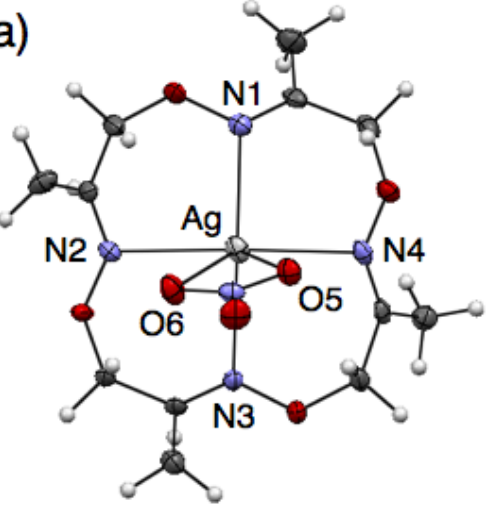

(d)

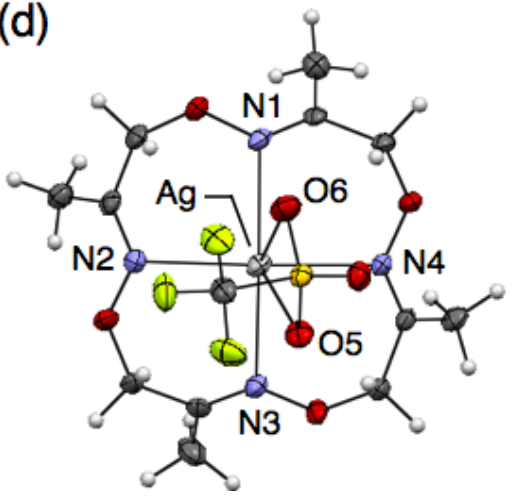

(b)

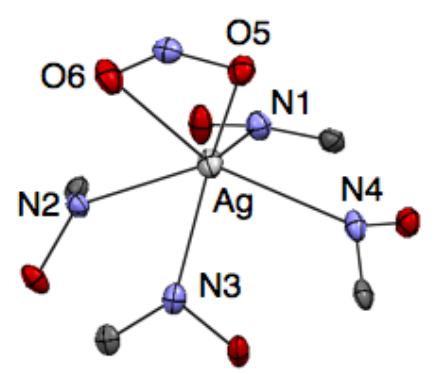

(e)

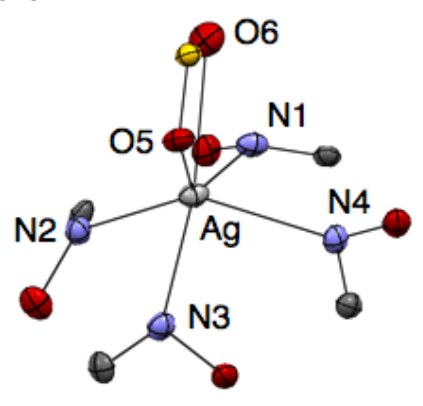

(c)

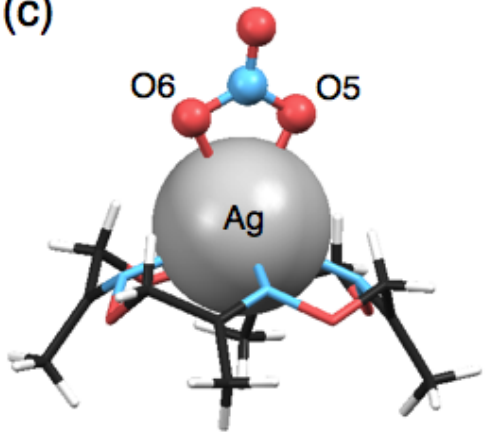

(f)

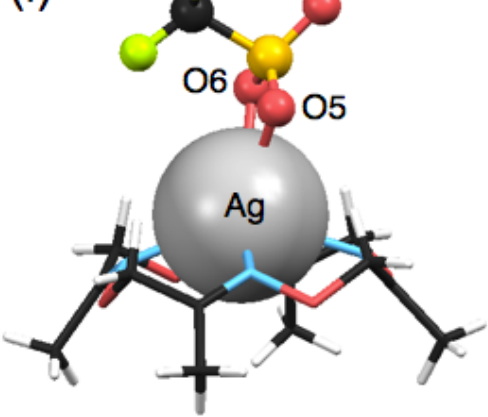

Crystallisation of a mixed solution of 1 with $\mathrm{AgCF}_{3} \mathrm{SO}_{3}$ in $\mathrm{CH}_{3} \mathrm{CN}$-toluene produced a similar complex, $\left[\mathrm{Ag}(\mathbf{1}) \mathrm{CF}_{3} \mathrm{SO}_{3}\right]$ (Figure 2(d)). This structure also has a shuttlecock-like structure with a six-coordinate $\mathrm{Ag}^{\mathrm{I}}$ ion bound by four nitrogen atoms of $\mathbf{1}$ and two oxygen atoms of a $\mathrm{CF}_{3} \mathrm{SO}_{3}{ }^{-}$anion (Figure 2(e,f)). This chiral complex $\left[\mathrm{Ag}(\mathbf{1}) \mathrm{CF}_{3} \mathrm{SO}_{3}\right]$ also exists as a racemate in the crystal. In comparing $\mathrm{Ag}-\mathrm{N}$ bond distances in both complexes, $\left[\mathrm{Ag}(\mathbf{1}) \mathrm{NO}_{3}\right]$ and $\left[\mathrm{Ag}(\mathbf{1}) \mathrm{CF}_{3} \mathrm{SO}_{3}\right]$, an average $\mathrm{Ag}-\mathrm{N}$ distance of $2.490 \AA$ for $\left[\mathrm{Ag}(\mathbf{1}) \mathrm{CF}_{3} \mathrm{SO}_{3}\right]$ is significantly shorter than that of $2.536 \AA$ for $\left[\mathrm{Ag}(\mathbf{1}) \mathrm{NO}_{3}\right]$ (Tables 2 and 3). In contrast, an average $\mathrm{Ag}-\mathrm{O}$ distance of $2.641 \AA$ for $\left[\mathrm{Ag}(\mathbf{1}) \mathrm{CF}_{3} \mathrm{SO}_{3}\right]$ is significantly longer than that of $2.513 \AA$ for $\left[\mathrm{Ag}(\mathbf{1}) \mathrm{NO}_{3}\right]$. This is probably due to the difference in the basicities of both anions, $\mathrm{CF}_{3} \mathrm{SO}_{3}{ }^{-}$and $\mathrm{NO}_{3}{ }^{-}$. 
Table 2. Selected bond lengths $(\AA)$ and angles $(\operatorname{deg})$ for $\left[\operatorname{Ag}(\mathbf{1}) \mathrm{NO}_{3}\right]$.

\begin{tabular}{llll}
\hline $\mathrm{Ag}(1)-\mathrm{N}(1)$ & $2.471(2)$ & $\mathrm{Ag}(1)-\mathrm{N}(2)$ & $2.530(3)$ \\
$\mathrm{Ag}(1)-\mathrm{N}(3)$ & $2.5945(17)$ & $\mathrm{Ag}(1)-\mathrm{N}(4)$ & $2.5476(15)$ \\
$\mathrm{Ag}(1)-\mathrm{O}(5)$ & $2.430(3)$ & $\mathrm{Ag}(1)-\mathrm{O}(6)$ & $2.5967(17)$ \\
$\mathrm{N}(1)-\mathrm{Ag}(1)-\mathrm{N}(2)$ & $83.96(7)$ & $\mathrm{N}(1)-\mathrm{Ag}(1)-\mathrm{N}(3)$ & $136.31(7)$ \\
$\mathrm{N}(1)-\mathrm{Ag}(1)-\mathrm{N}(4)$ & $81.03(6)$ & $\mathrm{N}(1)-\mathrm{Ag}(1)-\mathrm{O}(5)$ & $118.69(7)$ \\
$\mathrm{N}(1)-\mathrm{Ag}(1)-\mathrm{O}(6)$ & $125.67(6)$ & $\mathrm{N}(2)-\mathrm{Ag}(1)-\mathrm{N}(3)$ & $79.73(7)$ \\
$\mathrm{N}(2)-\mathrm{Ag}(1)-\mathrm{N}(4)$ & $133.00(7)$ & $\mathrm{N}(2)-\mathrm{Ag}(1)-\mathrm{O}(5)$ & $134.35(5)$ \\
$\mathrm{N}(2)-\mathrm{Ag}(1)-\mathrm{O}(6)$ & $83.44(7)$ & $\mathrm{N}(3)-\mathrm{Ag}(1)-\mathrm{N}(4)$ & $81.17(5)$ \\
$\mathrm{N}(3)-\mathrm{Ag}(1)-\mathrm{O}(5)$ & $101.31(7)$ & $\mathrm{N}(3)-\mathrm{Ag}(1)-\mathrm{O}(6)$ & $92.41(5)$ \\
$\mathrm{N}(4)-\mathrm{Ag}(1)-\mathrm{O}(5)$ & $91.41(7)$ & $\mathrm{N}(4)-\mathrm{Ag}(1)-\mathrm{O}(6)$ & $139.97(8)$ \\
$\mathrm{O}(5)-\mathrm{Ag}(1)-\mathrm{O}(6)$ & $50.94(6)$ & & \\
\hline
\end{tabular}

Table 3. Selected bond lengths $(\AA)$ and angles (deg) for $\left[\mathrm{Ag}(\mathbf{1}) \mathrm{CF}_{3} \mathrm{SO}_{3}\right]$.

\begin{tabular}{llll}
\hline $\mathrm{Ag}(1)-\mathrm{N}(1)$ & $2.489(3)$ & $\mathrm{Ag}(1)-\mathrm{N}(2)$ & $2.460(4)$ \\
$\mathrm{Ag}(1)-\mathrm{N}(3)$ & $2.512(3)$ & $\mathrm{Ag}(1)-\mathrm{N}(4)$ & $2.498(3)$ \\
$\mathrm{Ag}(1)-\mathrm{O}(5)$ & $2.588(3)$ & $\mathrm{Ag}(1)-\mathrm{O}(6)$ & $2.693(3)$ \\
$\mathrm{N}(1)-\mathrm{Ag}(1)-\mathrm{N}(2)$ & $83.44(10)$ & $\mathrm{N}(1)-\mathrm{Ag}(1)-\mathrm{N}(3)$ & $139.05(8)$ \\
$\mathrm{N}(1)-\mathrm{Ag}(1)-\mathrm{N}(4)$ & $83.41(10)$ & $\mathrm{N}(1)-\mathrm{Ag}(1)-\mathrm{O}(5)$ & $135.80(9)$ \\
$\mathrm{N}(1)-\mathrm{Ag}(1)-\mathrm{O}(6)$ & $83.08(8)$ & $\mathrm{N}(2)-\mathrm{Ag}(1)-\mathrm{N}(3)$ & $83.09(11)$ \\
$\mathrm{N}(2)-\mathrm{Ag}(1)-\mathrm{N}(4)$ & $139.73(8)$ & $\mathrm{N}(2)-\mathrm{Ag}(1)-\mathrm{O}(5)$ & $123.30(9)$ \\
$\mathrm{N}(2)-\mathrm{Ag}(1)-\mathrm{O}(6)$ & $116.62(9)$ & $\mathrm{N}(3)-\mathrm{Ag}(1)-\mathrm{N}(4)$ & $82.41(10)$ \\
$\mathrm{N}(3)-\mathrm{Ag}(1)-\mathrm{O}(5)$ & $82.90(8)$ & $\mathrm{N}(3)-\mathrm{Ag}(1)-\mathrm{O}(6)$ & $137.13(9)$ \\
$\mathrm{N}(4)-\mathrm{Ag}(1)-\mathrm{O}(5)$ & $91.77(9)$ & $\mathrm{N}(4)-\mathrm{Ag}(1)-\mathrm{O}(6)$ & $99.27(9)$ \\
$\mathrm{O}(5)-\mathrm{Ag}(1)-\mathrm{O}(6)$ & $54.28(8)$ & & \\
\hline
\end{tabular}

\subsection{A Discrete, Dimeric Silver Complex, $\left[\mathrm{Ag}_{2}(\mathbf{1})_{2}\right]\left(\mathrm{SbF}_{6}\right)_{2}$}

Crystallisation of a solution of $\mathbf{1}$ and five equivalents of $\mathrm{AgSbF}_{6}$ in $\mathrm{CHCl}_{3}$ yielded colorless block crystals composed of a cationic, dimeric silver complex, $\left[\mathrm{Ag}_{2}(\mathbf{1})_{2}\right]\left(\mathrm{SbF}_{6}\right)_{2}$, as proven by single-crystal $\mathrm{X}$-ray analysis (Figure 3(a)). In this structure, an $\mathrm{Ag}^{\mathrm{I}}$ ion sits on the three upturned nitrogen atoms of $\mathbf{1}$ to form a shuttlecock-like structure which is similar to the structures of $\left[\mathrm{Ag}(\mathbf{1}) \mathrm{NO}_{3}\right]$ and $\left[\mathrm{Ag}(\mathbf{1}) \mathrm{CF}_{3} \mathrm{SO}_{3}\right]$. However, another one nitrogen atom $\mathrm{N}(3)$ of $\mathbf{1}$ binds to another $\mathrm{Ag}^{\mathrm{I}}$ ion to form a dimeric complex $\left[\mathrm{Ag}_{2}(\mathbf{1})_{2}\right]^{2+}$ with a four-coordinate $\mathrm{Ag}^{\mathrm{I}}$ ion (Figure 3(b)). The average Ag-N distance of $2.421 \AA$ for $\left[\mathrm{Ag}_{2}(\mathbf{1})_{2}\right]^{2+}$ (Table 4) is obviously shorter than those of six-coordinate $\left[\mathrm{Ag}(\mathbf{1}) \mathrm{NO}_{3}\right]$ and $\left[\mathrm{Ag}(\mathbf{1}) \mathrm{CF}_{3} \mathrm{SO}_{3}\right]$. Notably, the resulting dimeric structure shows $\mathrm{Ag}^{\mathrm{I}}-\mathrm{Ag}^{\mathrm{I}}$ interactions with a distance of $3.364 \AA$, which is shorter than the sum of van der Waals radii $(\mathrm{Ag}-\mathrm{Ag}=3.44 \AA$ ) [23,24]. The dimeric structure with a pair of $\mathrm{Ag}^{\mathrm{I}}$ ions is composed of an enantiomeric pair arising from the chiral conformation of $\mathbf{1}$. In this crystal, the non-coordinating anions $\mathrm{SbF}_{6}^{-}$do not bind to $\mathrm{Ag}^{\mathrm{I}}$, but are accommodated in the bowlshaped pocket of $\mathbf{1}$ surrounded by four methyl groups (Figure 3(c)). 
Figure 3. Crystal structure of $\left[\mathrm{Ag}_{2}(\mathbf{1})_{2}\right]\left(\mathrm{SbF}_{6}\right)_{2}$. (a) A top view; and (b) the coordination structure represented with 50\% thermal ellipsoids; (c) A side view represented with space fill (Ag), stick (1) and ball-stick (counter anions) models.

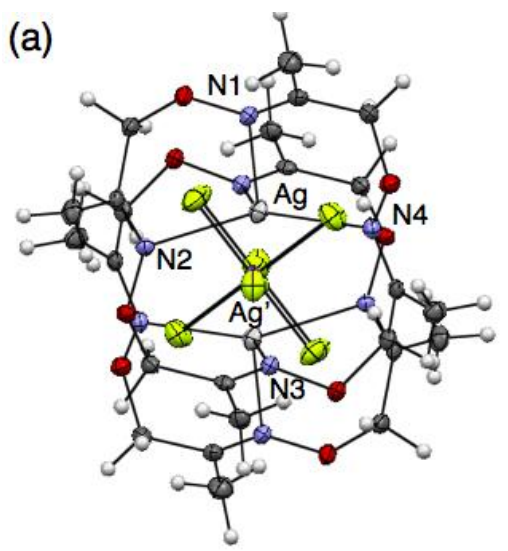

(b)

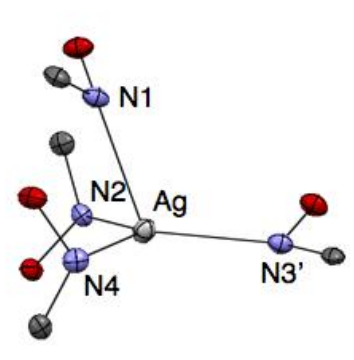

(c)

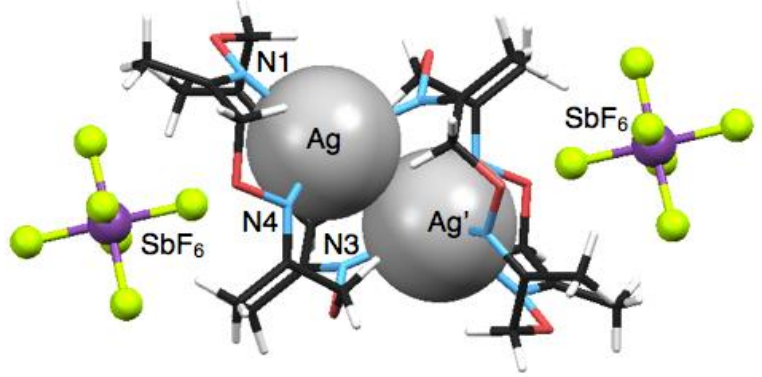

Table 4. Selected bond lengths $(\AA)$ and angles $(\operatorname{deg})$ for $\left[\mathrm{Ag}_{2}(\mathbf{1})_{2}\right]\left(\mathrm{SbF}_{6}\right)_{2}$.

\begin{tabular}{clcc}
\hline $\mathrm{Ag}(1)-\mathrm{N}(1)$ & $2.4203(17)$ & $\mathrm{Ag}(1)-\mathrm{N}(2)$ & $2.4999(16)$ \\
$\mathrm{Ag}(1)-\mathrm{N}\left(3^{\prime}\right)$ & $2.3320(17)$ & $\mathrm{Ag}(1)-\mathrm{N}(4)$ & $2.4307(18)$ \\
$\mathrm{Ag}(1)-\mathrm{Ag}\left(1^{\prime}\right)$ & $3.3636(3)$ & & \\
$\mathrm{N}(1)-\mathrm{Ag}(1)-\mathrm{N}(2)$ & $83.56(6)$ & $\mathrm{N}(1)-\mathrm{Ag}(1)-\mathrm{N}\left(3^{\prime}\right)$ & $115.83(6)$ \\
$\mathrm{N}(1)-\mathrm{Ag}(1)-\mathrm{N}(4)$ & $84.69(6)$ & $\mathrm{N}(2)-\mathrm{Ag}(1)-\mathrm{N}\left(3^{\prime}\right)$ & $108.38(6)$ \\
$\mathrm{N}(2)-\mathrm{Ag}(1)-\mathrm{N}(4)$ & $126.29(6)$ & $\mathrm{N}\left(3^{\prime}\right)-\mathrm{Ag}(1)-\mathrm{N}(4)$ & $123.82(6)$ \\
\hline
\end{tabular}

\subsection{A Polymeric Silver Complex Based on Mononuclear Units, $[\mathrm{Ag}(\mathbf{1})]_{n}\left(B F_{4}\right)_{n}$}

In contrast to the discrete structures described above, a polymeric, cationic silver complex, $[\mathrm{Ag}(\mathbf{1})]_{n}\left(\mathrm{BF}_{4}\right)_{n}$, was obtained from complexation of $\mathbf{1}$ with 10 equivalents of $\mathrm{AgBF}_{4}$. Upon slow evaporation of a mixed solution of both components in $\mathrm{CH}_{3} \mathrm{CN}$-toluene, colorless block crystals were obtained suitable for single-crystal X-ray analysis. In the crystal structure, ligand $\mathbf{1}$ adopts a non-chiral stair-like conformation and binds one $\mathrm{Ag}^{\mathrm{I}}$ ion that is disordered between two positions that are $1.466 \AA$ apart (0.5 occupancy each) (Figure 4(a)). The $\mathrm{Ag}^{\mathrm{I}}$ ion adopts a three-coordinate geometry with two shorter and one longer Ag-N distances of 2.249, 2.359 and 2.630 $\AA$, respectively (Table 5). For three nitrogen atoms bound to one $\mathrm{Ag}^{\mathrm{I}}$ ion, two nitrogen atoms come from one ligand and the third nitrogen atom from another neighboring ligand (Figure 4(b)), resulting in the connection of two macrocycles through one $\mathrm{Ag}^{\mathrm{I}}$ ion to form a polymeric structure (Figure 4(c)). Due to the disorder of $\mathrm{Ag}^{\mathrm{I}}$, although three kinds of $\mathrm{Ag}^{\mathrm{I}}-\mathrm{Ag}^{\mathrm{I}}$ distances are possible (3.190, 4.396 and $5.726 \AA$ ), the second shortest distance of $4.396 \AA$ appears to be more probable. The one-dimensional $\mathrm{Ag}^{\mathrm{I}}$ arrays are arranged parallel in the crystal packing structure. Counter anions, $\mathrm{BF}_{4}^{-}$, also are arranged linearly in the interstitial channels which are formed by the parallel packing of $\mathrm{Ag}^{\mathrm{I}}$ arrays. 
Figure 4. Crystal structure of $[\operatorname{Ag}(\mathbf{1})]_{n}\left(\mathrm{BF}_{4}\right)_{n}$. (a) A top view; and (b) the coordination structure represented with 50\% thermal ellipsoids; (c) A side view represented with space fill $(\mathrm{Ag})$ and stick (1) models. $\mathrm{BF}_{4}^{-}$anions and disordered $\mathrm{Ag}^{\mathrm{I}}$ cations are omitted for clarity in (b) and (c).

(a)

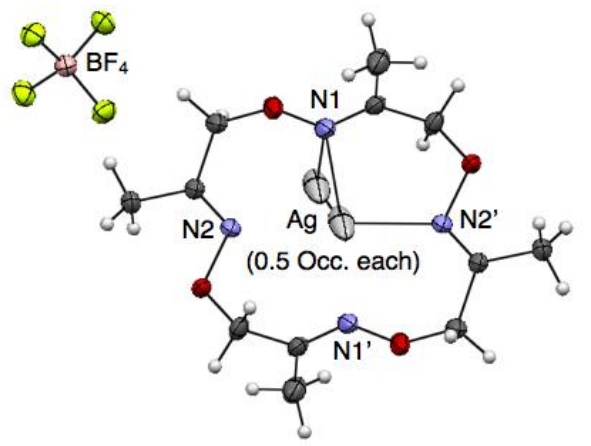

(b)

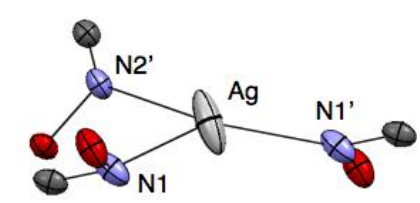

(c)

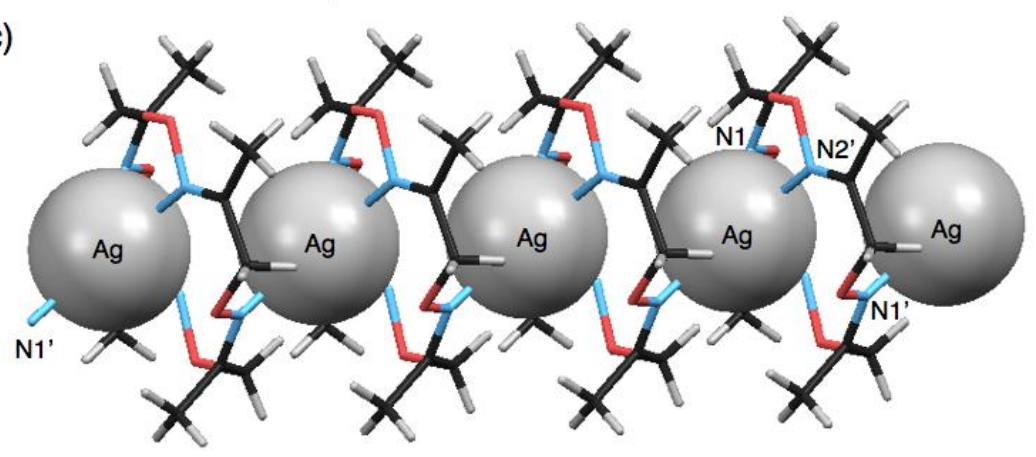

Table 5. Selected bond lengths $(\AA)$ and angles $(\operatorname{deg})$ for $[\mathrm{Ag}(\mathbf{1})]_{n}\left(\mathrm{BF}_{4}\right)_{n}$.

\begin{tabular}{llll}
\hline $\mathrm{Ag}(1)-\mathrm{N}(1)$ & $2.249(5)$ & $\mathrm{Ag}(1)-\mathrm{N}\left(1^{\prime}\right)$ & $2.359(6)$ \\
$\mathrm{Ag}(1)-\mathrm{N}\left(2^{\prime}\right)$ & $2.630(5)$ & & \\
$\mathrm{N}(1)-\mathrm{Ag}(1)-\mathrm{N}\left(1^{\prime}\right)$ & $143.0(3)$ & $\mathrm{N}(1)-\mathrm{Ag}(1)-\mathrm{N}\left(2^{\prime}\right)$ & $85.13(17)$ \\
$\mathrm{N}\left(1^{\prime}\right)-\mathrm{Ag}(1)-\mathrm{N}\left(2^{\prime}\right)$ & $122.60(16)$ & & \\
\hline
\end{tabular}

\subsection{A Polymeric Silver Complex Based on Dinuclear Units, $\left[\mathrm{Ag}_{2}(1)\left(\mathrm{NO}_{3}\right)_{2}\right]_{n}$}

Another polymeric silver complex was found as plate crystals from a mixed solution of $\mathbf{1}$ and 10 equivalents of $\mathrm{AgNO}_{3}$ in $\mathrm{CH}_{3} \mathrm{CN}$-toluene, which are different conditions from those used with the mononuclear complex, $\left[\mathrm{Ag}(\mathbf{1}) \mathrm{NO}_{3}\right]$, formed from the $\mathrm{CH}_{3} \mathrm{CN}$ solution as block crystals. The single-crystal X-ray analysis of the plate crystal revealed a unit structure of a neutral, dinuclear silver complex, $\left[\mathrm{Ag}_{2}(\mathbf{1})\left(\mathrm{NO}_{3}\right)_{2}\right]$, for a one-dimensional coordination polymer, $\left[\mathrm{Ag}_{2}(\mathbf{1})\left(\mathrm{NO}_{3}\right)_{2}\right]_{n}$. The stair-like conformation of $\mathbf{1}$ is almost the same as $[\mathrm{Ag}(\mathbf{1})]_{n}\left(\mathrm{BF}_{4}\right)_{n}$, thus $\mathbf{1}$ in $\left[\mathrm{Ag}_{2}(\mathbf{1})\left(\mathrm{NO}_{3}\right)_{2}\right]_{n}$ can also bind two $\mathrm{Ag}^{\mathrm{I}}$ ions to form a polymeric structure. Notably, the coordination polymer is composed of two kinds of $\left[\mathrm{Ag}_{2}(\mathbf{1})\left(\mathrm{NO}_{3}\right)_{2}\right]$ units. In one $\left[\mathrm{Ag}_{2}(\mathbf{1})\left(\mathrm{NO}_{3}\right)_{2}\right]$, the $\mathrm{Ag}(1)$ atom adopts a four-coordinate structure with two nitrogen atoms of the same 1 and two oxygen atoms of one $\mathrm{NO}_{3}{ }^{-}$anion (Figure 5(a-c)). Meanwhile, the other $\left[\mathrm{Ag}_{2}(\mathbf{1})\left(\mathrm{NO}_{3}\right)_{2}\right]$ contains a five-coordinate $\mathrm{Ag}(2)$ atom bound by two nitrogen atoms of 1 , two oxygen atoms of one $\mathrm{NO}_{3}{ }^{-}$anion and one oxygen atom of another $\mathrm{NO}_{3}{ }^{-}$ (Figure 5(d-f)). Importantly, both $\left[\mathrm{Ag}_{2}(\mathbf{1})\left(\mathrm{NO}_{3}\right)_{2}\right]$ structures show $\mathrm{Ag}^{\mathrm{I}}-\mathrm{Ag}^{\mathrm{I}}$ interactions with different distances $\left(\operatorname{Ag}(1)-\operatorname{Ag}\left(1^{\prime}\right): 3.235 \AA, \operatorname{Ag}(2)-\operatorname{Ag}\left(2^{\prime}\right): 3.348 \AA\right.$ ) (Table 6). 
Figure 5. Crystal structure of $\left[\mathrm{Ag}_{2}(\mathbf{1})\left(\mathrm{NO}_{3}\right)_{2}\right]_{n}$. (a-c) One $\left[\mathrm{Ag}_{2}(\mathbf{1})\left(\mathrm{NO}_{3}\right)_{2}\right]$ structure containing $\mathrm{Ag}(1)$; and $(\mathbf{d}-\mathbf{f})$ another $\left[\mathrm{Ag}_{2}(\mathbf{1})\left(\mathrm{NO}_{3}\right)_{2}\right]$ structure containing $\mathrm{Ag}(2)$. (a,d) Top views, (b,e) side views and (c,f) coordination structures represented with $50 \%$ thermal ellipsoids.

(a)



(d)

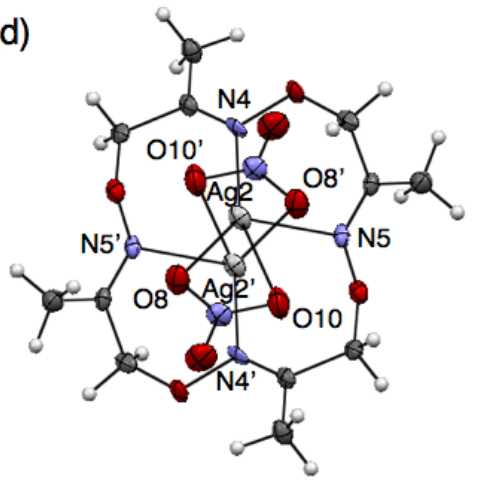

(b)

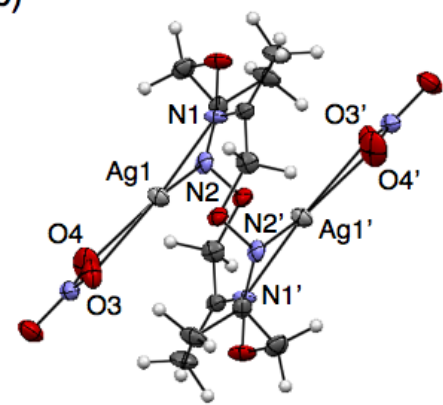

(e)

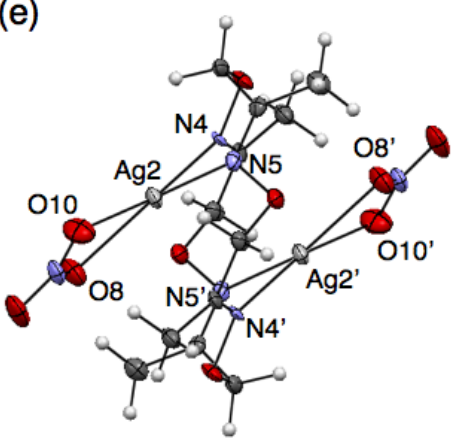

(c)

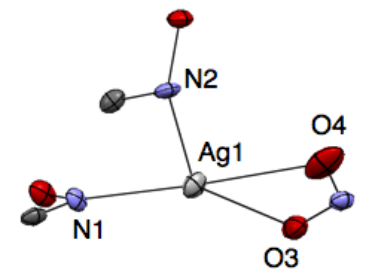

(f)



Table 6. Selected bond lengths $(\AA)$ and angles $(\mathrm{deg})$ for $\left[\mathrm{Ag}_{2}(\mathbf{1})\left(\mathrm{NO}_{3}\right)_{2}\right]_{n}$.

\begin{tabular}{llll}
\hline $\mathrm{Ag}(1)-\mathrm{N}(1)$ & $2.318(8)$ & $\mathrm{Ag}(1)-\mathrm{N}(2)$ & $2.493(6)$ \\
$\mathrm{Ag}(1)-\mathrm{O}(3)$ & $2.334(7)$ & $\mathrm{Ag}(1)-\mathrm{O}(4)$ & $2.647(8)$ \\
$\mathrm{Ag}(2)-\mathrm{N}(4)$ & $2.373(7)$ & $\mathrm{Ag}(2)-\mathrm{N}(5)$ & $2.429(6)$ \\
$\mathrm{Ag}(2)-\mathrm{O}\left(3^{\prime}\right)$ & $2.630(7)$ & $\mathrm{Ag}(2)-\mathrm{O}(8)$ & $2.338(6)$ \\
$\mathrm{Ag}(2)-\mathrm{O}(10)$ & $2.705(7)$ & $\mathrm{Ag}(1)-\mathrm{Ag}\left(1^{\prime}\right)$ & $3.2351(9)$ \\
$\mathrm{Ag}(2)-\mathrm{Ag}\left(2^{\prime}\right)$ & $3.3481(8)$ & $\mathrm{Ag}(1)-\mathrm{Ag}\left(2^{\prime}\right)$ & $3.7090(8)$ \\
$\mathrm{N}(1)-\mathrm{Ag}(1)-\mathrm{N}(2)$ & $81.7(3)$ & $\mathrm{N}(1)-\mathrm{Ag}(1)-\mathrm{O}(3)$ & $143.3(2)$ \\
$\mathrm{N}(1)-\mathrm{Ag}(1)-\mathrm{O}(4)$ & $163.1(3)$ & $\mathrm{N}(2)-\mathrm{Ag}(1)-\mathrm{O}(3)$ & $134.9(3)$ \\
$\mathrm{N}(2)-\mathrm{Ag}(1)-\mathrm{O}(4)$ & $85.4(3)$ & $\mathrm{O}(3)-\mathrm{Ag}(1)-\mathrm{O}(4)$ & $50.6(2)$ \\
$\mathrm{N}(4)-\mathrm{Ag}(2)-\mathrm{N}(5)$ & $80.1(2)$ & $\mathrm{N}(4)-\mathrm{Ag}(2)-\mathrm{O}\left(3^{\prime}\right)$ & $88.0(2)$ \\
$\mathrm{N}(4)-\mathrm{Ag}(2)-\mathrm{O}(8)$ & $143.9(2)$ & $\mathrm{N}(4)-\mathrm{Ag}(2)-\mathrm{O}(10)$ & $162.7(3)$ \\
$\mathrm{N}(5)-\mathrm{Ag}(2)-\mathrm{O}\left(3^{\prime}\right)$ & $115.0(3)$ & $\mathrm{N}(5)-\mathrm{Ag}(2)-\mathrm{O}(8)$ & $134.6(3)$ \\
$\mathrm{N}(5)-\mathrm{Ag}(2)-\mathrm{O}(10)$ & $90.4(2)$ & $\mathrm{O}\left(3^{\prime}\right)-\mathrm{Ag}(2)-\mathrm{O}(8)$ & $84.8(3)$ \\
$\mathrm{O}\left(3^{\prime}\right)-\mathrm{Ag}(2)-\mathrm{O}(10)$ & $83.0(3)$ & $\mathrm{O}(8)-\mathrm{Ag}(2)-\mathrm{O}(10)$ & $49.9(3)$ \\
\hline
\end{tabular}

Both $\left[\mathrm{Ag}_{2}(\mathbf{1})\left(\mathrm{NO}_{3}\right)_{2}\right]$ units are crookedly connected with each other through an $\mathrm{O}(3)$ atom of one $\mathrm{NO}_{3}{ }^{-}$anion (Figure 6(a,b)). The inter-unit $\mathrm{Ag}^{\mathrm{I}}-\mathrm{Ag}^{\mathrm{I}}$ distance of $3.709 \AA$ is relatively short. As the result of alternate arrangement of two $\left[\mathrm{Ag}_{2}(\mathbf{1})\left(\mathrm{NO}_{3}\right)_{2}\right]$ units, $\mathrm{Ag}^{\mathrm{I}}$ ions are aligned in a zigzag fashion (Figure 6(c)). In the crystal packing structure, the coordination polymers are arranged parallel and closely. 
Figure 6. Polymeric structure of $\left[\mathrm{Ag}_{2}(\mathbf{1})\left(\mathrm{NO}_{3}\right)_{2}\right]_{n}$ in the crystal. (a) A top view; and (b) a side view of a crookedly connected structure containing two $\left[\mathrm{Ag}_{2}(\mathbf{1})\left(\mathrm{NO}_{3}\right)_{2}\right]$ units; and (c) a polymeric structure represented with space fill $(\mathrm{Ag})$, stick (1) and ball-stick (counter anions) models.

(a)

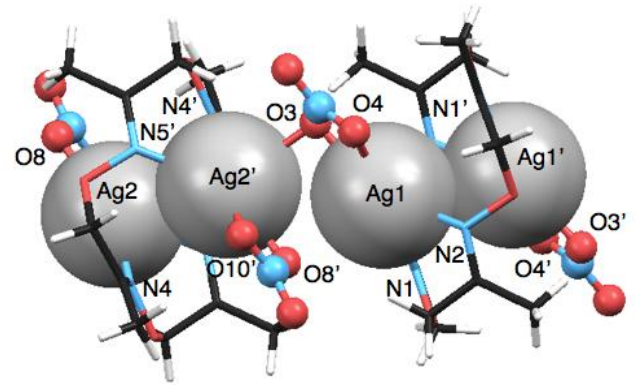

(b)

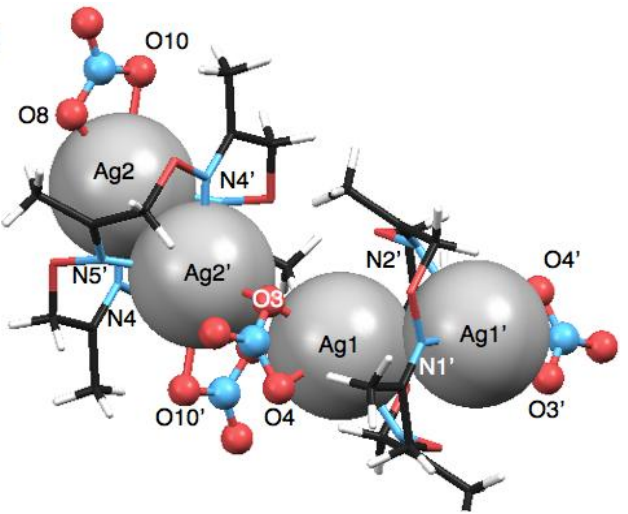

(c)

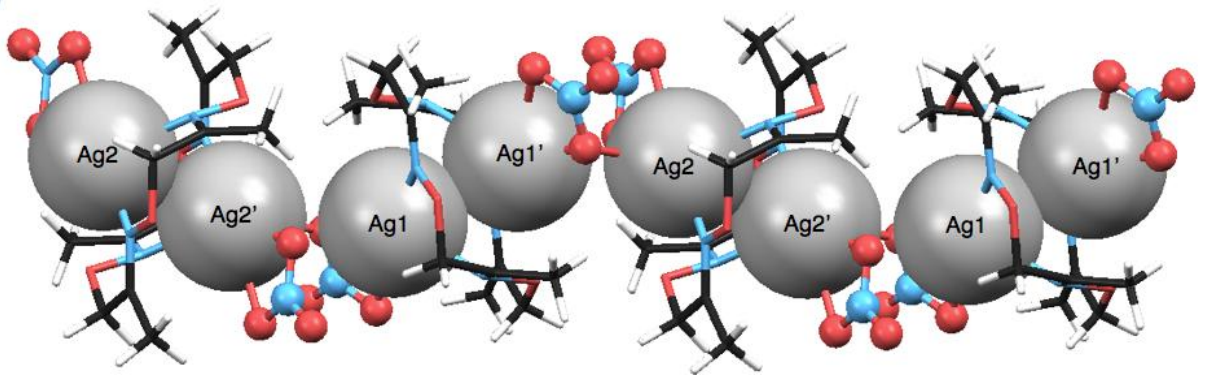

\section{Discussion}

\subsection{Ligand Conformation}

Macrocyclic ligands and their metal complexes such as crown ethers [25] and macrocyclic polyamines [26-28] have been well studied and discussed with regard to their conformation as one of the most important factors to determine their metal complexation behaviours. In this study, we have demonstrated the formation of several types of silver complexes of $\mathbf{1}$ with different coordination geometries, compositional ratios and packing structures. The main origin for the diverse structures appears to be the relatively flexible macrocyclic structure of $\mathbf{1}$ capable of adopting several different ring conformations. So far, at least four conformations of $\mathbf{1}$ were found in the single-crystal X-ray analyses. For example, two mononuclear complexes, $\left[\mathrm{Ag}(\mathbf{1}) \mathrm{NO}_{3}\right]$ and $\left[\mathrm{Ag}(\mathbf{1}) \mathrm{CF}_{3} \mathrm{SO}_{3}\right]$, and one dimeric complex, $\left[\mathrm{Ag}_{2}(\mathbf{1})_{2}\right]\left(\mathrm{SbF}_{6}\right)_{2}$, adopt shuttlecock-like conformations (Figure 7(a)). In these cases, $\mathrm{Ag}^{\mathrm{I}}$ ions sit on the four nitrogen atoms of $\mathbf{1}$ due to the large ionic radius of $\mathrm{Ag}^{\mathrm{I}}$. Interestingly, a mononuclear complex, $\left[\mathrm{Ag}(\mathbf{1}) \mathrm{CF}_{3} \mathrm{CO}_{2}\right]$, previously reported [16] has a similar but significantly different conformation of $\mathbf{1}$, that is regarded as a flipped shuttlecock-like conformation in which one nitrogen atom is oriented to the opposite face (Figure 7(b)). The differences in the crystal packing, counter anions and crystallisation conditions might cause the partial flipping of the shuttlecock-like conformation of $\mathbf{1}$. 
Figure 7. Top and side views of four conformations of ligand $\mathbf{1}$ in each complex. (a) A shuttlecock-like conformation in $\left[\mathrm{Ag}(\mathbf{1}) \mathrm{CF}_{3} \mathrm{SO}_{3}\right]$; (b) A flipped shuttlecock-like conformation in $\left[\mathrm{Ag}(\mathbf{1}) \mathrm{CF}_{3} \mathrm{CO}_{2}\right][16]$; (c) A stair-like conformation in $[\mathrm{Ag}(\mathbf{1})]_{n}\left(\mathrm{BF}_{4}\right)_{n}$; (d) A planar conformation in $\left[\mathrm{Ni}(\mathbf{1})\left(\mathrm{CH}_{3} \mathrm{CN}\right)_{2}\right]\left(\mathrm{ClO}_{4}\right)_{2}[16]$.

(a)

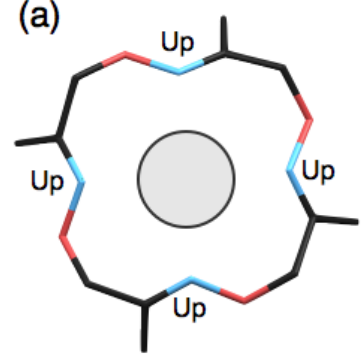

(b)



(c)

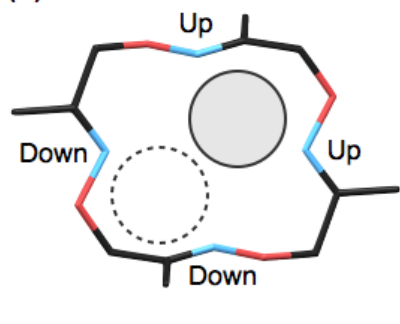

(d)



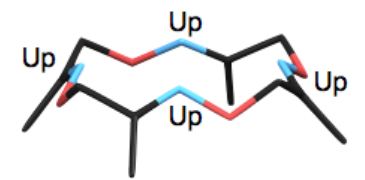
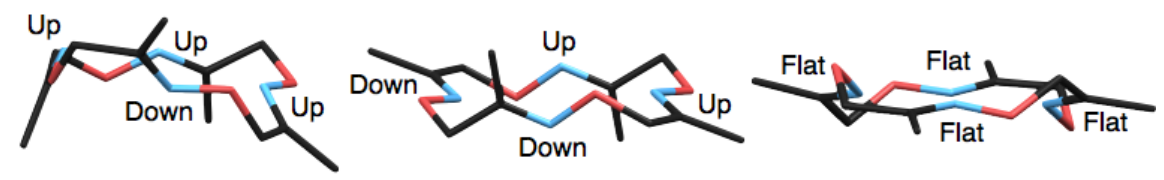

In contrast to the discrete complexes, the present polymeric complexes, $[\operatorname{Ag}(\mathbf{1})]_{n}\left(\mathrm{BF}_{4}\right)_{n}$ and $\left[\mathrm{Ag}_{2}(\mathbf{1})\left(\mathrm{NO}_{3}\right)_{2}\right]_{n}$, and previously reported $\left[\mathrm{Ag}_{2}(\mathbf{1})\left(\mathrm{CF}_{3} \mathrm{CO}_{2}\right)_{2}\right]_{n}[16]$, possess a stair-like conformation of $\mathbf{1}$, in which two nitrogen atoms and the other two atoms of $\mathbf{1}$ are oriented to upper and lower faces, respectively (Figure 7(c)). As the result, one macrocycle 1 can bind two $\operatorname{Ag}^{\mathrm{I}}$ ions on both faces simultaneously to form polymeric structures. It should be also noted that the stair-like conformation is quite similar to the conformation of metal-free ligand 1 [16], suggesting that the polymer formation of silver complexes of $\mathbf{1}$ seems to be less strained, predictable structures.

The last planar conformation of $\mathbf{1}$ found previously [16] is similar to those of conventional tetraaza macrocyclic complexes (Figure 7(d)). In our previous study, this conformation was exclusively observed with divalent transition metal complexes in a six-coordinate octahedral geometry such as $\left[\mathrm{Fe}(\mathbf{1})\left(\mathrm{CH}_{3} \mathrm{CN}\right)_{2}\right]\left(\mathrm{ClO}_{4}\right)_{2},\left[\mathrm{Ni}(\mathbf{1})\left(\mathrm{CH}_{3} \mathrm{CN}\right)_{2}\right]\left(\mathrm{ClO}_{4}\right)_{2},\left[\mathrm{Ni}(\mathbf{1})\left(\mathrm{H}_{2} \mathrm{O}\right)_{2}\right]\left(\mathrm{ClO}_{4}\right)_{2},\left[\mathrm{Cu}(\mathbf{1})\left(\mathrm{ClO}_{4}\right)_{2}\right]$ and $[\mathrm{Pd}(\mathbf{1})]\left(\mathrm{BF}_{4}\right)_{2}[16]$. This result indicates that the combination of larger $\mathrm{Ag}^{\mathrm{I}}$ ions and the structurally flexible ligand 1 allows the formation of diverse and unique silver complexes. This finding is expected to provide further information on further functionalisation of tetraoxime macrocycle $\mathbf{1}$ as a metal-selective chemosensor or a template for multi-metal assemblies.

\section{2. $A g^{I}-A g^{I}$ Interactions and $A g^{I}$ Arrays}

Construction of $\mathrm{Ag}^{\mathrm{I}}-\mathrm{Ag}^{\mathrm{I}}$ bonded $\mathrm{Ag}^{\mathrm{I}}$ chain arrays in crystals has attracted much attention in the fields of crystal engineering, supramolecular chemistry and metal-organic frameworks, because the $\mathrm{Ag}^{\mathrm{I}}$ ion possesses flexible coordination geometries and labile and diverse bonding manners such as $\mathrm{Ag}^{\mathrm{I}}-\mathrm{N}, \mathrm{Ag}^{\mathrm{I}}-\pi, \mathrm{Ag}^{\mathrm{I}}-\mathrm{Ag}^{\mathrm{I}}[29,30]$. Therefore, a novel molecular platform for $\mathrm{Ag}^{\mathrm{I}}$-based coordination polymers would make a significant contribution to this research area. In this study, several types of crystalline $\mathrm{Ag}^{\mathrm{I}}$ complexes were constructed, in which the $\mathrm{Ag}^{\mathrm{I}}-\mathrm{Ag}^{\mathrm{I}}$ distances varied due to the structural flexibility of $\mathbf{1}$. For example, in three mononuclear discrete complexes, $\left[\operatorname{Ag}(\mathbf{1}) \mathrm{NO}_{3}\right]$, $\left[\mathrm{Ag}(\mathbf{1}) \mathrm{CF}_{3} \mathrm{SO}_{3}\right]$ and $\left[\mathrm{Ag}(\mathbf{1}) \mathrm{CF}_{3} \mathrm{CO}_{2}\right], \mathrm{Ag}^{\mathrm{I}}$ ions are chemically isolated. On the other hand, the dimeric complex, $\left[\mathrm{Ag}_{2}(\mathbf{1})_{2}\right]\left(\mathrm{SbF}_{6}\right)_{2}$, possesses an isolated $\mathrm{Ag}^{\mathrm{I}}$-pair with $\mathrm{Ag}^{\mathrm{I}}-\mathrm{Ag}^{\mathrm{I}}$ interaction $\left(\mathrm{Ag}^{\mathrm{I}}-\mathrm{Ag}^{\mathrm{I}} \operatorname{distance}\right.$ : 
$3.364 \AA$ ) (Figure $8(\mathrm{a})$ ). The polymeric complex based on mononuclear units, $[\operatorname{Ag}(\mathbf{1})]_{n}\left(\mathrm{BF}_{4}\right)_{n}$, does not include any $\mathrm{Ag}^{\mathrm{I}}-\mathrm{Ag}^{\mathrm{I}}$ interactions, but forms a one-dimensional $\mathrm{Ag}^{\mathrm{I}}$ array in the crystal [Figure 8(b)]. In contrast, the polymeric complex based on dinuclear units, $\left[\mathrm{Ag}_{2}(\mathbf{1})\left(\mathrm{NO}_{3}\right)_{2}\right]_{n}$, allows the formation of an $\mathrm{Ag}^{\mathrm{I}}$ array involving two different $\mathrm{Ag}^{\mathrm{I}}-\mathrm{Ag}^{\mathrm{I}}$ distances of 3.235 and $3.348 \AA$ (Figure 8(c)). Interestingly, a polymeric complex, $\left[\mathrm{Ag}_{2}(\mathbf{1})\left(\mathrm{CF}_{3} \mathrm{CO}_{2}\right)_{2}\right]_{n}$, with different counter anions forms a similar $\mathrm{Ag}^{\mathrm{I}}$ array but with longer $\mathrm{Ag}^{\mathrm{I}}-\mathrm{Ag}^{\mathrm{I}}$ distances of 3.671 and $4.756 \AA$ (Figure 8(d)) [16]. These results suggest that the alignment properties of $\mathrm{Ag}^{\mathrm{I}}$ complexes in the crystal states would vary with the coordinating counter anions of silver salts. In addition, crystallisation condition is an important factor to determine the crystal packing structures of the silver complexes of $\mathbf{1}$.

Figure 8. Several $\mathrm{Ag}^{\mathrm{I}}$ arrangement structures in $(\mathbf{a})\left[\mathrm{Ag}_{2}(\mathbf{1})_{2}\right]\left(\mathrm{SbF}_{6}\right)_{2} ;(\mathbf{b})[\mathrm{Ag}(\mathbf{1})]_{n}\left(\mathrm{BF}_{4}\right)_{n}$; (c) $\left[\mathrm{Ag}_{2}(\mathbf{1})\left(\mathrm{NO}_{3}\right)_{2}\right]_{n}$; and (d) $\left[\mathrm{Ag}_{2}(\mathbf{1})\left(\mathrm{CF}_{3} \mathrm{CO}_{2}\right)_{2}\right]_{n}[16]$.

(a)

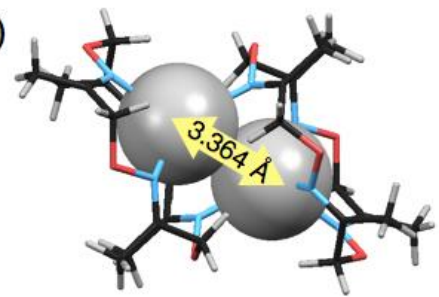

$\left[\mathrm{Ag}_{2}(\mathbf{1})_{2}\right]\left(\mathrm{SbF}_{6}\right)_{2}$

(c)



$\left[\mathrm{Ag}_{2}(\mathbf{1})\left(\mathrm{NO}_{3}\right)_{2}\right]_{n}$ (b)

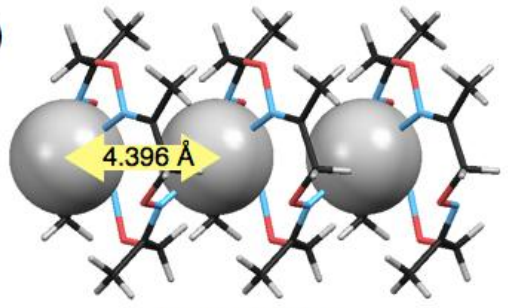

$[\mathrm{Ag}(\mathbf{1})]_{n}\left(\mathrm{BF}_{4}\right)_{n}$

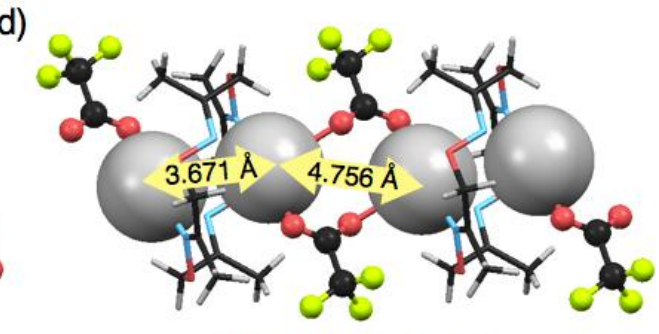

$\left[\mathrm{Ag}_{2}(\mathbf{1})\left(\mathrm{CF}_{3} \mathrm{CO}_{2}\right)_{2}\right]_{n}$

\subsection{Prospects for Chemosensors Using 1}

Finally, prospects for chemosensors using $\mathbf{1}$ are the development of different types of crystals of mononuclear, dinuclear and polymeric silver complexes with various $\mathrm{Ag}^{\mathrm{I}}-\mathrm{Ag}^{\mathrm{I}}$ distances depending on the kind of counter anions. If each crystal exhibits optical and electrical properties specific to the structural factors such as nucleus number and metal-metal distance, ligand $\mathbf{1}$ would serve as an anion sensor through metal-induced crystallisation. Due to its structural flexibility, ligand $\mathbf{1}$ can also complex with various transition metal ions such as $\mathrm{Fe}^{\mathrm{II}}, \mathrm{Ni}^{\mathrm{II}}, \mathrm{Cu}^{\mathrm{II}}, \mathrm{Pd}^{\mathrm{II}}$ and $\mathrm{Ag}^{\mathrm{I}}$ [16], suggesting the potential of $\mathbf{1}$ as cation sensors or other functional materials as demonstrated in recent progress of coordination chemistry [31,32].

\section{Conclusions}

In this study, we demonstrated the structural diversity of tetraoxime macrocyclic silver complexes to bring out the potential of $\mathbf{1}$ as a macrocyclic chemosensor. Single-crystal X-ray analyses revealed the molecular structures of five silver complexes of $\mathbf{1}$. Depending on the kinds of counter anions and ring conformation of $\mathbf{1}$, two discrete mononuclear complexes, $\left[\mathrm{Ag}(\mathbf{1}) \mathrm{NO}_{3}\right]$ and $\left[\mathrm{Ag}(\mathbf{1}) \mathrm{CF}_{3} \mathrm{SO}_{3}\right]$, one 
discrete dimeric complex, $\left[\mathrm{Ag}_{2}(\mathbf{1})_{2}\right]\left(\mathrm{SbF}_{6}\right)_{2}$, one polymeric complex based on mononuclear units, $[\mathrm{Ag}(\mathbf{1})]_{n}\left(\mathrm{BF}_{4}\right)_{n}$ and one polymeric complex based on dinuclear units, $\left[\mathrm{Ag}_{2}(\mathbf{1})\left(\mathrm{NO}_{3}\right)_{2}\right]_{n}$, were constructed. The crystal packing structures of these complexes possessed different arrangement patterns of $\mathrm{Ag}^{\mathrm{I}}$ ions. Importantly, some silver complexes can induce $\mathrm{Ag}^{\mathrm{I}}-\mathrm{Ag}^{\mathrm{I}}$ interactions in the crystals. These results unambiguously demonstrate the structural diversity of $\mathbf{1}$ leading to a new macrocyclic platform for chemosensors.

\section{Acknowledgments}

This study was supported by the Global COE Program and KAKENHI, the Japan Society for the Promotion of Science (JSPS) and MEXT (Japan). M. Y. thanks JSPS for the JSPS Research Fellowship for Young Scientists.

\section{Conflict of Interest}

The authors declare no conflict of interest.

\section{References}

1. Gokel, G.W.; Leevy, W.M.; Weber, M.E. Crown ethers: Sensors for ions and molecular scaffolds for materials and biological models. Chem. Rev. 2004, 104, 2723-2750.

2. Kang, S.O.; Llinares, J.M.; Day, V.W.; Bowman-James, K. Cryptand-like anion receptors. Chem. Soc. Rev. 2010, 39, 3980-4003.

3. Kimura, E. Macrocyclic polyamines with intelligent functions. Tetrahedron 1992, 48, 6175-6217.

4. Sessler, J.L.; Seidel, D. Synthetic expanded porphyrin chemistry. Angew. Chem. Int. Ed. 2003, 42, 5134-5175.

5. Guerriero, P.; Tamburini, S.; Vigato, P.A. From mononuclear to polynuclear macrocyclic or macroacyclic complexes. Coord. Chem. Rev. 1995, 139, 17-243.

6. Valeur, B.; Leray, I. Design principles of fluorescent molecular sensors for cation recognition. Coord. Chem. Rev. 2000, 205, 3-40.

7. Beer, P.D.; Gale, P.A. Anion recognition and sensing: The state of the art and future perspectives. Angew. Chem. Int. Ed. 2001, 40, 486-516.

8. De Silva, A.P.; Gunaratne, H.Q.N.; Gunnlaugsson, T.; Huxley, A.J.M.; McCoy, C.P.; Rademacher, J.T.; Rice, T.E. Signaling recognition events with fluorescent sensors and switches. Chem. Rev. 1997, 97, 1515-1566.

9. De Silva, A.P.; Fox, D.B.; Huxley, A.J.M.; Moody, T.S. Combining luminescence, coordination and electron transfer for signalling purposes. Coord. Chem. Rev. 2000, 205, 41-57.

10. Martínez-Máñez, R.; Sancenón, F. Fluorogenic and chromogenic chemosensors and reagents for anions. Chem. Rev. 2003, 103, 4419-4476.

11. Beer, P.D.; Cadman, J. Electrochemical and optical sensing of anions by transition metal based receptors. Coord. Chem. Rev. 2000, 205, 131-155.

12. Nguyen, B.T.; Anslyn, E.V. Indicator-displacement assays. Coord. Chem. Rev. 2006, 250, 3118-3127. 
13. Ariga, K.; Ito, H.; Hill, J.P.; Tsukube, H. Molecular recognition: From solution science to nano/materials technology. Chem. Soc. Rev. 2012, 41, 5800-5835.

14. Ariga, K.; Vinu, A.; Yamauchi, Y.; Ji, Q.; Hill, J.P. Nanoarchitectonics for mesoporous materials. Bull. Chem. Soc. Jpn. 2012, 85, 1-32.

15. Leung, K.C.-F.; Chak, C.-P.; Lo, C.-M.; Wong, W.-Y.; Xuan, S.; Cheng, C.H.K. pH-controllable supramolecular systems. Chem. Asian J. 2009, 4, 364-381.

16. Tashiro, S.; Minoda, A.; Yamada, M.; Shionoya, M. One-pot, template syntheses of a new class of metallomacrocycles with a tetraoxime cyclic skeleton. Inorg. Chem. 2009, 48, 10093-10101.

17. Pyykkö, P. Strong closed-shell interactions in inorganic chemistry. Chem. Rev. 1997, 97, 597-636.

18. Katz, M.J.; Sakai, K.; Leznoff, D.B. The use of aurophilic and other metal-metal interactions as crystal engineering design elements to increase structural dimensionality. Chem. Soc. Rev. 2008, $37,1884-1895$.

19. Hissler, M.; McGarrah, J.E.; Connick, W.B.; Geiger, D.K.; Cummings, S.D.; Eisenberg, R. Platinum diimine complexes: Towards a molecular photochemical device. Coord. Chem. Rev. 2000, 208, 115-137.

20. Wang, M.-S.; Guo, S.-P.; Li, Y.; Cai, L.-Z.; Zou, J.-P.; Xu, G.; Zhou, W.-W.; Zheng, F.-K.; Guo, G.-C. A direct white-light-emitting metal-organic framework with tunable yellow-to-white photoluminescence by variation of excitation light. J. Am. Chem. Soc. 2009, 131, 13572-13573.

21. Ray, L.; Shaikh, M.M.; Ghosh, P. Shorter argentophilic interaction than aurophilic interaction in a pair of dimeric $\{(\mathrm{NHC}) \mathrm{MCl}\}_{2}(\mathrm{M}=\mathrm{Ag}, \mathrm{Au})$ complexes supported over a N/O-Functionalized N-Heterocyclic Carbene (NHC) ligand. Inorg. Chem. 2008, 47, 230-240.

22. Sheldrick, G.M. SHELXL-97, Program for Refinement of Crystal Structures; University of Göttingen: Göttingen, Germany, 1997.

23. Bondi, A. van der Waals Volumes and Radii. J. Phys. Chem. 1964, 68, 441-451.

24. Singh, K.; Long, J.R.; Stavropoulos, P. Ligand-unsupported metal-metal $(\mathrm{M}=\mathrm{Cu}, \mathrm{Ag})$ interactions between closed-shell $\mathrm{d}^{10}$ trinuclear systems. J. Am. Chem. Soc. 1997, 119, 2942-2943.

25. Troxler, L.; Wipff, G. Conformation and dynamics of 18-Crown-6, Cryptand 222, and their cation complexes in acetonitrile studied by molecular dynamics simulations. J. Am. Chem. Soc. 1994, 116, 1468-1480.

26. Thöm, V.J.; Fox, C.C.; Boeyens, J.C.A.; Hancock, R.D. Molecular mechanics and crystallographic study of hole sizes in nitrogen-donor tetraaza macrocycles. J. Am. Chem. Soc. 1984, 106, 5947-5955.

27. Pérez, J.; Carrascosa, R.; García, L.; Barandika, G.; Calderón-Casado, A.; Pérez, E.; Serrano, J.L.; Santana, M.D. Coordination to metal centers: A tool to fix high energy conformations in organic molecules. Application to 2,4,4-trimethyl-1,5,9-triazacyclododec-1-ene and related macrocycles. Dalton Trans. 2011, 40, 9504-9511.

28. Curtis, N.F. Configurational isomerism of 2,5,5,7,9,12,12,14-Octamethyl-1,4,8,11tetraazacyclotetradecane and its compounds. Coord. Chem. Rev. 2012, 256, 878-895.

29. Khlobystov, A.N.; Blake, A.J.; Champness, N.R.; Lemenovskii, D.A.; Majouga, A.G.; Zyk, N.V.; Schröder, M. Supramolecular design of one-dimensional coordination polymers based on silver(I) complexes of aromatic nitrogen-donor ligands. Coord. Chem. Rev. 2001, 222, 155-192. 
30. Chen, C.-L.; Kang, B.-S.; Su, C.-Y. Recent advances in supramolecular design and assembly of silver(I) coordination polymers. Aust. J. Chem. 2006, 59, 3-18.

31. Lasanta, T.; Olmos, M.E.; Laguna, A.; López-de-Luzuriaga, J.M.; Naumov, P. Making the golden connection: Reversible mechanochemical and vapochemical switching of luminescence from bimetallic gold-silver clusters associated through aurophilic interactions. J. Am. Chem. Soc. 2011, 133, 16358-16361.

32. Sakata, Y.; Furukawa, S.; Kim, C.; Kitagawa, S. Formation of nanocrystals of a zinc pillared-layer porous coordination polymer using microwave-assisted coordination modulation. Chem. Lett. 2012, 41, 1436-1438.

(C) 2013 by the authors; licensee MDPI, Basel, Switzerland. This article is an open access article distributed under the terms and conditions of the Creative Commons Attribution license (http://creativecommons.org/licenses/by/3.0/). 